\title{
A Study of the Cell Envelope of the Halobacteria
}

\author{
By HEIDI STEENSLAND* AND H. LARSEN \\ Department of Biochemistry, The Technical University of Norway, \\ Trondheim, Norway
}

(Accepted for publication 17 October 1968)

\begin{abstract}
SUMMARY
Electron microscopy on thin sections of three different extremely halophilic Halobacterium species showed that their cell envelopes were of similar general construction: an inner membrane and an outer layer. The outer layer stains most strongly in the outermost part. When the $\mathrm{NaCl}$ concentration of the environment was lowered from the optimal of $4.3 \mathrm{M}$ to $2.2 \mathrm{M}$ the outer layer of the cell envelope of Halobacterium salinarium strain I became frayed; in many cells a release of material from the outer layer appeared to take place. When the cells were exposed to distilled water the outer layer of the envelope appeared to dissolve completely and the cell membrane disintegrated into tiny flakes. Fragments of the cell envelope produced by mechanical disintegration of the cells in $4.3 \mathrm{M}-\mathrm{NaCl}$ formed closed vesicles very rapidly; some of the cytoplasmic material became trapped inside the vesicles. Detergents appeared to slow down the closing of the vesicles and also to cause a release of material from the outer layer of the cell envelope. The cell envelope vesicles were mainly composed of protein and lipid; their content of amino sugar was low compared with the cell envelope of other Gram-negative bacteria. The cell envelope vesicle also contained nucleic acids; most of these were probably parts of the cytoplasmic material trapped inside the vesicles. The amino acid composition showed that the protein of the cell envelope vesicles was quite acidic, consistent with the contention that high concentrations of sodium ions stabilize the cell envelopes of these organisms by neutralizing the negative charges of the protein. Upon centrifugation at high speed of the lysate obtained by dialysis of the cell envelope vesicles against distilled water, the fragments of the cell membrane sedimented whereas most of the protein, presumably from the outer layer of the cell envelope, stayed in the supernatant fraction. Carotenoids and cytochromes were contained in the sediment with the membrane fragments. Most of the amino sugar-containing components stayed in the supernatant fraction; in the presence of $10-25 \mathrm{~mm}$ salt most of the amino sugar-containing components sediment with the membrane fragments.
\end{abstract}

\section{INTRODUCTION}

Stoeckenius \& Rowen (1966, 1967) and Cho, Doy \& Mercer (1967) showed with improved techniques for electron microscopy that the anatomy of the cell envelope of Halobacterium halobium is more complex than indicated by earlier studies (Larsen, 1967). The envelope appears to be composed of an inner membrane having the appearance and the dimensions of a 'unit membrane', and an outer 2-layered structure, 75-150 $\AA$ in thickness, which was shown by Stoeckenius \& Rowen (1967) to be

* Present address: Department of Biochemistry and Molecular Biology, Cornell University, Ithaca, New York 14850. 
proteinaceous in nature. The studies of Stoeckenius \& Rowen (1967) have also led to a more detailed insight into the process of lysis of $H$. halobium in hypotonic solutions. Upon dilution with water of the strongly saline $(4-4.5 \mathrm{M}-\mathrm{NaCl})$ environment in which the halobacteria live, protein is released from the outer layer of the cell envelope; at higher dilutions the cell membrane disintegrates to fragments of varying sizes.

In the present work the anatomy of the cell envelopes of three other extremely halophilic bacteria of the Halobacterium type has been studied. One of them, Halobacterium salinarium, strain $\mathrm{I}$, appears to contain a less complex system of membranes than $H$. halobium and was selected for chemical studies of the cell envelope and the pattern of its disintegration in hypotonic solutions. A short account of some of the results has. already been given (Steensland, 1967).

\section{METHODS}

Organisms. Halobacterium salinarium strain I (Mohr \& Larsen, 1963) and Halobacterium sp. strain 5 (Larsen, Omang \& Steensland, 1967) are slender regular rods when grown in liquid cultures. The latter organism produces gas vacuoles; the former does not. The third organism used in the present work was kindly given to us by Dr G. Penso; he assigned this organism to the genus Amoebobacter Winogradsky and named it Amoebobacter morrhuae (Penso, 1947). This organism bears, however, little relation to the genus Amoebobacter. It is an extremely halophilic organism of the Halobacterium type (Larsen, 1962), but in contrast to the two organisms mentioned above the organisms are irregular in shape.

Cultivation. The organisms were grown at $30^{\circ}$ on a reciprocating shaker (84 oscillations $/ \mathrm{min}$. of excursion $5 \mathrm{~cm}$.) in $500 \mathrm{ml}$. flasks containing $120 \mathrm{ml}$. of a medium of the following composition $(\%, w / v): 25$, solar salt (Trapani); I, $\mathrm{MgSO}_{4} .7 \mathrm{H}_{2} \mathrm{O} ; 0.5$, $\mathrm{KCl} ; 0.02, \mathrm{CaCl}_{2} .6 \mathrm{H}_{2} \mathrm{O} ; 0.5$, tryptone (Oxoid); $\mathrm{IO}(\mathrm{v} / \mathrm{v})$, yeast autolysate (Mohr \& Larsen, 1963); in tap water; $\mathrm{pH} 7$. The salts and the organic nutrients were sterilized separately, the salt solution after being filtered through cotton wool. The cultures were harvested at the end of the exponential growth phase.

Chemicals. Except for the solar salt used in the growth medium all chemicals were of the highest purity available commercially.

Preparation of cell envelope fragments of $H$. salinarium strain $I$. The contents of many culture flasks were pooled and kept aerated until fed into a Sharples (open type motor drive) supercentrifuge at $-10^{\circ}$. The subsequent operations were done at $0^{\circ}$. The packed organisms were disintegrated mechanically by stirring the paste with a glass rod as described by Holmes, Dundas \& Halvorson (1965). The viscous mass obtained by this treatment was suspended in 5 vol. of $4 \cdot 3 \mathrm{M}-\mathrm{NaCl}$ and homogenized in a MSE Homogenizer at full speed for $30 \mathrm{sec}$. The suspension was centrifuged (Servall SS-3) at $4000 \mathrm{~g}$ (10 min.). The sediment was discharged and the supernatant fluid recentrifuged at $27,000 \mathrm{~g}(\mathrm{I} \mathrm{hr})$. The new sediment containing the cell envelope fragments was washed $2-4$ times and suspended in 5 vol. of $4 \cdot 3 \mathrm{M}-\mathrm{NaCl}$. The washed suspension was stored at $-8^{\circ}$. In some of the preparations a solution containing $4.3 \mathrm{M}-\mathrm{NaCl}$ and $0.025 \mathrm{M}-\mathrm{MgCl}_{2}$ was used for suspending and washing the cell-envelope fragments.

For the preparation of cell-envelope fragments with detergents, packed organisms from the Sharples centrifuge were suspended in 5 vol. of $4.3 \mathrm{M}-\mathrm{NaCl}$ containing $2 \%$ Tween 80 (Koch-Light, England) or $0.005 \%$ Triton X 100 (Serva, West Germany); 
3 vol. of glass beads (Ballotini, no. 12) were added and the suspensions homogenized for $3 \mathrm{~min}$. in the MSE Homogenizer run at full speed. The glass beads were removed by passing through a coarse sintered glass filter (no. I) and the suspension was centrifuged in the Servall centrifuge as described above; $4.3 \mathrm{M}-\mathrm{NaCl}$ was used to wash and suspend the cell-envelope fragments.

\section{Preparations for electron microscopy}

Thin sections. I vol. of culture or cell-envelope suspension was mixed with I vol. of the Glauert \& Thornley (1966) glutaraldehyde fixative in $4.3 \mathrm{M}-\mathrm{NaCl}(5 \%$ glutaraldehyde in 0.I M-Na cacodylate- $\mathrm{HCl} \mathrm{pH} \mathrm{7.I,} 0.01 \mathrm{M}-\mathrm{CaCl}_{2}, 4.3 \mathrm{M}-\mathrm{NaCl}$ ) and kept in the cold for I $\mathrm{hr}$. The organisms were sedimented at $1000 \mathrm{~g}(5 \mathrm{~min}$.) and the cell-envelope fragments at 27,000 $\mathrm{g}$ ( $15 \mathrm{~min}$.) The sedimented material was washed three times by centrifugation at $\mathrm{I} \mathrm{hr}$ intervals in the cold in $0 . \mathrm{I} \mathrm{M}$-cacodylate $+4.3 \mathrm{M}-\mathrm{NaCl}$. The sediments were treated in the cold overnight with the Kellenberger, Ryter \& Séchaud (1958) osmium tetroxide fixative (without tryptone) in $4.3 \mathrm{M}-\mathrm{NaCl}$. The subsequent operations were done at room temperature. The sediments were washed with 6 vol. of the Kellenberger et al. (1958) acetate + veronal buffer in $4.3 \mathrm{M}-\mathrm{NaCl}$ and then treated with the Kellenberger et al. (1958) uranyl acetate washing fluid in $4 \cdot 3 \mathrm{M}-\mathrm{NaCl}$ ( $30 \mathrm{~min}$.). The preparations of whole organisms were embedded in $2 \%$ agar (Difco) in $4.3 \mathrm{M}-\mathrm{NaCl}$; the preparations of cell-envelope fragments were not. Both types of preparations were dehydrated in ethanol + water mixtures saturated with $\mathrm{NaCl}$, taken up in acetone and embedded in Vestopal 310 (Chemische Werke Hüls A.-G., West Germany), using I \% Trigonox CM-50 and 0.03\% Co-naphthenate (Noury \& van der Lande, Holland) as initiator and accelerator, respectively. The blocks were sectioned in a Leitz Ultramicrotome with a glass knife. The sections were stained with $2 \%$ uranyl acetate $(15 \mathrm{~min}$.) and $0.002 \%$ lead citrate $(3 \mathrm{~min}$.). The preparations were examined with the Siemens Elmiskop at $80 \mathrm{kV}$.

In some experiments the $\mathrm{NaCl}$ concentration in cultures and suspensions of cellenvelope fragments was decreased to $2 \cdot 2 \mathrm{M}$ by dialysis 3 times ( $\mathrm{I} \mathrm{hr}$ ) against $100 \mathrm{vol}$. of $2 \cdot 2 \mathrm{M}-\mathrm{NaCl}$, before preparation for electron microscopy. The preparations for sectioning were made as described above, with the modification that all solutions contained $2 \cdot 2 \mathrm{M}-\mathrm{NaCl}$ instead of $4 \cdot 3 \mathrm{M}-\mathrm{NaCl}$.

Fragments of cell membranes obtained upon removal of $\mathrm{NaCl}$ by dialysis were sedimented in the Spinco model L ultracentrifuge at $140,000 \mathrm{~g}$ and prepared for sectioning by treating the sediment with half-strength glutaraldehyde fixative; otherwise as described above, but $\mathrm{NaCl}$ was omitted from all solutions.

Carbon replicas of whole organisms and cell-envelope fragments were made as described by Mohr \& Larsen (1963).

\section{Analytical methods}

Salt-free dry weight was determined in preparations dialysed against water, by drying a sample at $105^{\circ}$ to constant weight and subtracting the ash remaining after heating to $400^{\circ}$ for $2-4 \mathrm{hr}$.

Total nitrogen was determined by the micro-Kjeldahl method (Reiner, 194I). $\mathrm{N} \times 6.25$ was taken as a measure of protein.

Amino acids. For the determination of amino acid composition of proteins the preparations were hydrolysed in $6 \mathrm{~N}-\mathrm{HCl}$ at $110^{\circ}(40 \mathrm{hr})$. Particles in the hydrolysate 
were removed by filtration and $\mathrm{HCl}$ removed by evaporation under reduced pressure over solid $\mathrm{NaOH}$. The amino acids were chromatographed according to Moore, Spackman \& Stein (1958) and estimated according to Yemm \& Cocking (1955). Expected loss of serine (20\%) and threonine (10\%) during hydrolysis was corrected for (Tristram \& Smith, 1962). Cysteine and half-cystine were determined according to Moore (1963), tryptophan according to Noltmann, Mahowald \& Kuby (1962). To test for diaminopimelic acid the hydrolysate was chromatographed on paper according to Rhuland, Work, Denman \& Hoare (1955). The part of the paper where diaminopimelic acid should collect, was cut out and eluted separately. The eluate was chromatographed according to Moore et al. (1958).

Total lipid was extracted by the method of Folch, Lees \& Stanley (1957) and determined gravimetrically.

Amino sugar. The preparations to be analysed were hydrolysed in $4 \mathrm{~N}-\mathrm{HCl}$ at $105^{\circ}$ $(4 \mathrm{hr})$. The hydrochloric acid was evaporated under reduced pressure and amino sugar was determined by the method of Rondle \& Morgan (1955) and expressed as glucosamine.

Carotenoids were extracted in acetone + water $(2+\mathrm{I}, \mathrm{v} / \mathrm{v})$, transferred to ether and estimated spectrophotometrically (Zeiss PMQ II) at $499 \mathrm{~m} \mu ; E_{1 \mathrm{~m}}^{1 \%}=2620$ (Liaaen Jensen, 1960).

Cytochromes. Difference spectra were obtained with the Zeiss PMQ II spectrophotometer by running two cuvettes containing the same amount of preparation against each other, some crystals of $\mathrm{Na}_{2} \mathrm{~S}_{2} \mathrm{O}_{4}$ being added to one of the cuvettes. An estimate of the amount of cytochrome was obtained from the difference between the maximum and the minimum optical densities in the Soret region of the spectrum.

In separation experiments using the phase distribution method (Albertsson, 1960) the two-phase system contained $5 \%$ dextran $\left(\mathrm{D}_{500}\right), 4 \%$ polyethylene glycol $\left(\mathrm{PEG}_{6000}\right)$ in $0.02 \mathrm{M}-\mathrm{K}$-phosphate ( $\mathrm{pH} \mathrm{6.8)}$ and $0-0.05 \mathrm{M}-\mathrm{NaCl}$. The polymers were kindly given to us by Professor Albertsson. Rough estimates were made of nucleic acids and protein according to the method of Warburg \& Christian (Layne, 1957).

\section{RESULTS}

\section{Observations in the electron microscope}

Organisms kept at optimal $\mathrm{NaCl}$ concentration. Plate I, fig. I and 2 show thin sections of Halobacterium salinarium strain I and Halobacterium sp. strain 5, respectively. Care had been taken to keep the organisms at optimal $(4 \cdot 3 \mathrm{M}) \mathrm{NaCl}$ concentration during the preparations for the sectioning. The cells appear to have an outer layer varying in thickness (60-150 $\AA$ ) from cell to cell. This layer stained unevenly and the outermost part most strongly, indicating a two-layered structure. Many sections of Halobacterium sp. strain 5 showed a dented appearance of the cell surface, and with a spacing of about $\mathrm{r} 40 \AA$ (Pl. I, fig. 2). This structure presumably relates to the pattern of hexagonally arranged pebble-like structures observed in shadowed preparations of halobacteria (Larsen, 1967). In sections of $H$. salinarium strain I the dented appearance of the surface was not so clearly recognizable (Pl. I, fig. I) although replicas of the surface show that this organism possesses the hexagonal surface patten (Mohr \& Larsen, 1963).

Plate I, fig. I and 2 reveal an electron transparent layer of about $30 \AA$ in thickness 
next to the outer layer, and bonded by thin stained layers. This indicates a membrane structure. The membrane structure was not, however, clearly recognizable in most sections prepared of cells kept at optimal $\mathrm{NaCl}$ concentration, and its significance became clear only from the experiments reported below in which the cells were exposed to hypotonic conditions.

Sections of the halobacterium of Penso gave the same general picture of the fine structure of the cell envelope as described for the two organisms above.

Organisms exposed to half strength $\mathrm{NaCl}$ concentration. Upon lowering the $\mathrm{NaCl}$ concentration in the cultures of Halobacterium salinarium strain I from the optimal of 4.3 M to 2.2 M, thin sections of the cells appeared as shown in Pl. I, fig. 3 and 4 . Some of cells were disrupted and partly emptied of their content; others were not disrupted. In the whole cells the outer layer appeared characteristically frayed (Pl. I, fig. 3) as compared to cells not exposed to hypotonic conditions (Pl. I, fig. I), and the membrane structure stood out quite clearly in most of the cells. In the disrupted cells most of the outer layer was missing (PI. I, fig. 4); the material appeared to be released. The three-layered membrane structure, however, could be clearly recognized but appeared broken. The membrane measured about $80 \AA$ in thickness. Upon examination of a number of sections it appeared quite striking that the undisrupted cells possessed the outer layer whereas the disrupted cells had lost most of this layer.

Replicas of the surface showed that all cells exposed to the hypotonic condition, regardless of whether they were disrupted or not, had lost the hexagonal pattern so characteristic of the cells kept at optimal $\mathrm{NaCl}$ concentration.

Cell-envelope fragments kept at optimal $\mathrm{NaCl}$ concentration. Plate 2, fig. 5 shows a section of cell envelope fragments of Halobacterium salinarium strain I. The $\mathrm{NaCl}$ concentration was kept at $4 \cdot 3 \mathrm{M}$ during the preparation of the fragments. The difference in magnification from the figures on Plate I should be noted. The cell-envelope fragments all appear as closed vesicles. When liberated by the mechanical rupture of the cells the fragments of the cell envelope apparently close themselves rapidly by fusion along the line of shear. Some of the cytoplasmic material is trapped inside the vesicles and cannot be removed by washing in the centrifuge. In Pl. 2, fig. 5 the cytoplasmic membrane can be seen as part of the envelope structure. The outer layer of the envelope does not appear as distinct as in sections of whole cells. However, in replicas of the surface the hexagonal pattern was clearly seen, indicating that the outer layer is indeed present in the washed fragments of the cell envelope kept in $4.3 \mathrm{M}-\mathrm{NaCl}$.

Plate 2, fig. 6 and 7 show sections of cell-envelope fragments treated with Tween 80 and Triton X 100, respectively. By this treatment the vesicles appear completely emptied of cytoplasmic material indicating that the detergents slowed down the closing of the vesicles or possibly prevented the vesicles from closing completely. Treatment with detergents also removed most, or possibly all, of the outer layer of the envelope, leaving the three-layered membrane structure. Another result of the treatment with detergents was the rather frequent finding in the sections of one or more vesicles inside another (P1. 2, fig. 7).

Cell-envelope fragments exposed to hypotonic solutions. Upon decreasing the $\mathrm{NaCl}$ concentration in the suspension of cell-envelope fragments of Halobacterium salinarium strain I from $4.3 \mathrm{M}$ to $2 \cdot 2 \mathrm{M}$ by dialysis, replicas of the surface of the fragments revealed that the hexagonal pattern was lost. Sections of the fragments showed that little was left of the outer layer of the cell envelope in most of the fragments, but the 
cytoplasmic membrane remained apparently intact. Most of the fragments still appeared in the sections as vesicles, but they were emptied of cytoplasmic material which indicated that they were ruptured. In many of the vesicles gaps were observed as visible evidence of disruption; some of the vesicles even appeared completely unfolded. Decreasing the $\mathrm{NaCl}$ concentration from 4.3 to $2.2 \mathrm{M}$ thus appeared to result in a dissolution of material from the outer layer and an opening of the vesicles.

Cell-envelope fragments suspended in a solution of $4 \cdot 3 \mathrm{M}-\mathrm{NaCl}+0.025 \mathrm{M}-\mathrm{MgCl}_{2}$ were dialysed against $0.025 \mathrm{M}-\mathrm{MgCl}_{2}$ to remove $\mathrm{NaCl}$. The sediment obtained by centrifugation at $140,000 \mathrm{~g}$ ( $\mathrm{I} \mathrm{hr}$ ) appeared in sections as shown in Pl. 2, fig. 8. Only the membrane appeared to be left of the organized structure. A disruption of most of the membranes had taken place. Upon dialysis of the cell-envelope fragments against distilled water a sediment was obtained in the ultracentrifuge which appeared in sections as shown in Pl. 2, fig. 9. An extensive disruption of the membrane had taken place by the latter treatment; the membrane appears as tiny flakes.

\section{Chemical studies}

The chemical studies were done on Halobacterium salinarium strain I.

Composition of cell-envelope vesicles. Cell-envelope fragments, isolated in $4.3 \mathrm{M}-$ $\mathrm{NaCl}$ and forming vesicles as illustrated in Pl. 2, fig. 5, were dialysed against water. The opaque suspension became transparent by this treatment. Nitrogen was not lost from the dialysis bag according to Kjeldahl analyses. Table I, column 2 shows that

\section{Table I. Chemical composition of cell envelope vesicles and 'cell membranes' of Halobacterium salinarium strain I}

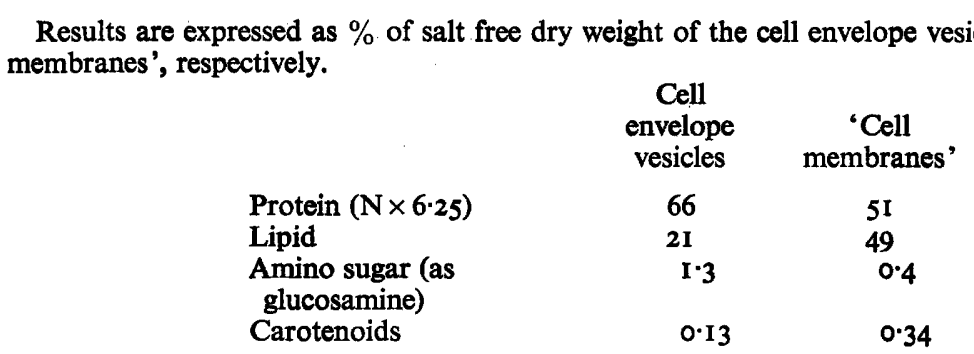

the bulk of the dialysed material is made up of protein $(\mathrm{N} \times 6.25)$ and lipid. The amount of amino sugar (estimated as glucosamine) was low compared to cell envelope preparations of other types of bacteria, but fits quite well with the data given for other halobacteria (Brown \& Shorey, 1963; Kushner et al. 1964; Brown, Shorey \& Turner, 1965).

The components given for cell-envelope vesicles added up to somewhat less than $90 \%$ of the salt free dry weight. The bulk of the remainder consisted of nucleic acids, both RNA and DNA. This was evidenced by spectrophotometric data and by gel filtration on Sephadex G I00 of the dialysed cell-envelope material after treatment with RNase and DNase. Each of the nucleases gave rise to low molecular nucleotidic material that was separated from the protein and lipid on the Sephadex column. The latter components filtered quantitatively through the column with no retention. At first the nucleic acids seemed rather firmly bound to the cell envelope in their native 
state since they could not be removed by repeated washing of the cell envelope fragments in the centrifuge. However, using the phase distribution method of Albertsson (I960) on dialysed preparations of the cell-envelope fragments the nucleic acids were separated from protein and lipid. Somewhat later the vesicular nature of the cellenvelope fragments was realized and it then appeared probable that the nucleic acids, or at least a good deal of them, were contaminants from the cytoplasmic material trapped in the vesicles.

Table 2. Amino acid content of cell-envelope vesicles of Halobacterium salinarium strain $I$

\begin{tabular}{|c|c|c|c|}
\hline & $\begin{array}{l}\text { Anhydro amino } \\
\text { acid/I0o mg. } \\
\text { salt-free } \\
\text { dry weight } \\
\text { (mg.) }\end{array}$ & $\begin{array}{l}\text { Anhydro amino } \\
\text { acid/100 mg. } \\
\text { salt-free } \\
\text { dry weight } \\
\text { ( } \mu \text { mole) }\end{array}$ & Mole (\%) \\
\hline Aspartic acid & 10.5 & 91 & 14.0 \\
\hline Glutamic acid & 9.8 & 76 & II. 6 \\
\hline $\mathrm{NH}_{3}{ }^{*}$ & $(1 \cdot 3)$ & (94) & - \\
\hline Lysine & 1.8 & 14 & $2 \cdot 2$ \\
\hline Arginine & $2 \cdot 7$ & 17 & $2 \cdot 7$ \\
\hline Histidine & 0.9 & 6 & $1 \cdot 0$ \\
\hline Glycine & $3 \cdot 6$ & 62 & $9 \cdot 6$ \\
\hline Alanine & $4 \cdot 2$ & 59 & $9 \cdot 1$ \\
\hline Valine & $5 \cdot 6$ & 57 & $8 \cdot 7$ \\
\hline Leucine & $5 \cdot 3$ & 47 & $7 \cdot 2$ \\
\hline Isoleucine & $3 \cdot 3$ & 28 & $4 \cdot 4$ \\
\hline Serine & $4 \cdot 6$ & 56 & 8.5 \\
\hline Threonine & 6.2 & $6 I$ & 9.4 \\
\hline Cystine/2 ) & & & \\
\hline Cysteine $\}$ & 0.3 & 2 & 0.3 \\
\hline Methionine & $\mathrm{I} \cdot 7$ & 13 & $I \cdot 9$ \\
\hline Proline & $2 \cdot 3$ & 24 & $3 \cdot 6$ \\
\hline Hydroxyproline $\dagger$ & - & - & - \\
\hline Phenylalanine & $2 \cdot 9$ & 20 & $3 \cdot 0$ \\
\hline Tyrosine & $2 \cdot 8$ & 17 & $2 \cdot 6$ \\
\hline Tryptophan & 0.4 & 2 & 0.3 \\
\hline Sum & $68 \cdot 9$ & 652 & 100 \\
\hline
\end{tabular}

The amino acid content of the dialysed cell-envelope material was determined after treatment with RNase and DNase and removal of the nucleotides on Sephadex G 100 (Table 2). The amino acid residues added up to about $69 \%$ of the salt-free dry weight; this figure was a measure of the protein content of the preparation. The ammonia probably stemmed almost entirely from the amide group of the aspartic and glutamic acids since the lipid was low in nitrogen (less than $0.3 \%$; Urdahl, unpublished) and this nitrogen could not easily give rise to ammonia in the hydrolysis of the preparation. The contribution to ammonia from amino sugar must also be small. The data thus suggest that $50-55 \%$ of the aspartic and glutamic acids were present in the cellenvelope vesicles as amides. Diaminopimelic acid was not detected in the eluate from the ion exchange column. In order to detect small amounts of this compound it was enriched for on paper as described under Methods and the proper fraction tested on the ion exchange column. Diaminopimelic acid could still not be detected. Hence, if 
present, diaminopimelic acid would make up less than $0.001 \%$ of the salt-free dry weight of the cell envelope vesicles.

Composition of sedimentable and non-sedimentable fractions of the cell-envelope vesicles after removal of $\mathrm{NaCl}$. Cell-envelope vesicles suspended in $4 \cdot 3 \mathrm{M}-\mathrm{NaCl}$ were dialysed against water, the dialysate was treated with RNase and DNase and centrifuged at $140,000 \mathrm{~g}(3 \mathrm{hr})$. A red transparent sediment was formed; the supernatant fluid appeared colourless. The distribution of the components of the material between sediment and supernatant fluid is given in Table 3. It appears that the non-sedimentable fraction was enriched in protein and amino sugar; the sedimentable fraction was strongly enriched in lipid and contained practically all the carotenoid. The nucleotides liberated by the nuclease treatment remained in the supernatant fluid.

Table 3. Distribution between sediment and supernatant fluid of the components of the cell-envelope vesicles after dialysis against water and centrifugation at $140,000 \mathrm{~g}(3 \mathrm{hr})$

Results are expressed as \% of salt free dry weight of the cell envelope vesicles.

$\begin{array}{lcc} & \text { Sediment } & \text { Supernatant } \\ \text { Protein }(\mathrm{N} \times 6.25) & 19 & 47 \\ \text { Lipid } & 16 & 7 \\ \begin{array}{l}\text { Amino sugar (as } \\ \text { glucosamine) }\end{array} & 0.25 & 1 \cdot 0 \\ \text { Carotenoids } & & \\ \text { Sum } & 0.11 & 0.002 \\ & 35.3 & 55.0\end{array}$

About one-third of the dialysed material of the cell-envelope vesicles sedimented in the ultracentrifuge. The sediment contained the cell membranes in the form of tiny flakes as illustrated in Pl. 2, fig. 9, whereas the supernatant fluid presumably contained the bulk of the material of the outer layer of the cell envelope. The membrane flakes were washed twice in the ultracentrifuge with water containing a small amount of $\mathbf{M g}^{2+}$ which facilitated their sedimentation. The washed preparation had a composition as shown in Table I, column 3. The high content of lipid should be noted. In addition to the carotenoids, the cytochromes of the cell-envelope vesicles appeared to collect quantitatively in the sedimented membrane fraction. Both these components were contained in the membrane fraction at a concentration about 3 times as high as in the cell-envelope vesicles, and their content in the membrane fraction became constant by washing in the centrifuge. The difference spectrum of the cytochromes in the washed membrane fraction showed absorption maxima at 560, 525 and $430 \mathrm{~m} \mu$ typical of cytochromes of the b-type.

Sedimentability of amino sugar-containing cell-envelope components at low salt concentrations. After dialysis of the suspension of cell-envelope vesicles in $4 \cdot 3 \mathrm{M}-\mathrm{NaCl}$ against water, only about one-fifth of the amino sugar-containing components sedimented with the cell membrane flakes in the ultracentrifuge (Table 3). The rest remained in the supernatant fluid even after prolonged centrifugation. $\mathrm{Mg}^{2+}$ in relatively modest concentrations greatly facilitated the sedimentation of the membrane flakes, and the sediment under these conditions contained a considerably higher proportion of the amino sugar-containing components (Table 4). When the suspension of cell-envelope vesicles in $4.3 \mathrm{M}-\mathrm{NaCl}$ is dialysed against various salts in the concentration range I I-25 mM, $60-75 \%$ of the amino sugar-containing components of the cell-envelope 
vesicles apparently sedimented in the ultracentrifuge with the cell-membrane flakes. When the vesicles were dialysed against $2 \mathrm{mM}-\mathrm{MgCl}_{2}$ (i.e. the concentration of $\mathrm{MgCl}_{2}$ used for the activation of DNase in the experiments described above) or against distilled water, only about $20 \%$ of the amino sugar-containing components sedimented.

Table 4. Sedimentability of amino sugar-containing components after dialysis of cellenvelope vesicles in $4.3 \mathrm{M}-\mathrm{NaCl}$ against various dilute salt solutions

The centrifuge was run at $144,000 \mathrm{~g}$ until the red pigment (i.e. presumably the membrane flakes) had quantitatively sedimented.

\begin{tabular}{|c|c|c|}
\hline & $\begin{array}{l}\text { Time of } \\
\text { centrifuga- } \\
\text { tion } \\
\text { (hr) }\end{array}$ & $\begin{array}{c}\text { Total amino- } \\
\text { sugar } \\
\text { sedimented } \\
(\%)\end{array}$ \\
\hline $\begin{array}{l}0.01 \mathrm{M}-\mathrm{K} \text {-phosphate, pH } 5.9 \\
0.01 \mathrm{M}-\mathrm{K} \text {-phosphate, pH } 7.6\end{array}$ & $\begin{array}{l}9 \\
9\end{array}$ & $\begin{array}{l}74 \\
69\end{array}$ \\
\hline $0.025 \mathrm{M}-\mathrm{MgCl}_{2}$ & I & 70 \\
\hline $0.012 \mathrm{M}-\mathrm{MgCl}_{2}$ & I & 60 \\
\hline $0.02 \mathrm{M}-\mathrm{NaCl}$ & 5 & 59 \\
\hline $0.002 \mathrm{M}-\mathrm{MgCl}_{2}$ & 8 & 23 \\
\hline Distilled water & 5 & 23 \\
\hline
\end{tabular}

\section{DISCUSSION}

The electron microscope studies on the fine structure of the cell envelope of the three different halobacteria reported in the present work agree in essence with those reported earlier for Halobacterium halobium by Stoeckenius \& Rowen $(1966,1967)$ and Cho et al. (1967); an inner membrane having the appearance and dimensions of a 'unit membrane' and an outer layer staining most heavily in the outermost part seems to be a structure common to the cell envelopes of halobacteria.

Halobacterium salinarium strain I was affected by hypotonic conditions in much the same way as Stoeckenius \& Rowen (1967) reported for H. halobium. A decrease of the $\mathrm{NaCl}$ concentration caused a release of the outer layer of the cell envelope; upon further dilution of the environment with water the cell membrane disintegrated to tiny flakes. However, Stoeckenius \& Rowen observed little change in the fine structure of $H$. halobium until a dilution of $\mathrm{I} \cdot \mathrm{O} \mathrm{M}-\mathrm{NaCl}$ was reached. In the present studies, $H$. salinarium strain I showed characteristic changes in the fine structure of the cell envelope upon dilution of the $\mathrm{NaCl}$ concentration to $2 \cdot 2 \mathrm{M}-\mathrm{NaCl}$. In sections the outer layer appeared frayed; a good proportion of the cells were ruptured and in these cells it could be observed that a release of the outer layer had taken place. It thus seems that $H$. salinarium strain $\mathrm{I}$ is more halophilic than $H$. halobium in this respect, and resembles $H$. cutirubrum for which a significant release of protein from cell envelope preparations was reported to take place at $\mathrm{NaCl}$ concentrations of $2 \cdot 0-3.0 \mathrm{M}$ (Onishi \& Kushner, 1966).

Halobacterium salinarium strain I appears to be equipped with a less complex system of membranes than $H$. halobium. In the latter organism Stoeckenius \& Rowen (1967) identified three different types of membranes, one 'intracytoplasmic', one 'purple coloured' and one 'red-to-orange coloured'. The latter two types of membranes could be separated by centrifugation of lysates of the cells in pure water; the purple membrane sedimented easily, the red-to-orange membrane only at very high 
forces of gravity. Intracytoplasmic membranes were not observed in sections of $H$. salinarium strain $I$ and no evidence was found for an easily sedimentable membrane in lysates of the cells. The only type of membrane identified in sections of this organism was the membrane of the cell envelope and this appears to correspond, both in colour and sedimentation character, to the red-to-orange membrane of $H$. halobium.

By mechanical disintegration of Halobacterium salinarium strain I in $4.3 \mathrm{M}-\mathrm{NaCl}$ the cell-envelope fragments formed closed vesicles immediately. Vesicle formation by fragments of biological membranes is a well-known phenomenon, and it was also observed by Stoeckenius \& Rowen (1967) in their work on cell-envelope fragments of $H$. halobium. Possibly this phenomenon is a characteristic of all halobacteria, but it has been overlooked in earlier work on their cell envelope. It is clear that the formation of closed vesicles makes it difficult to prepare 'pure' envelopes or envelope fragments by the customary procedure which involves breaking the cells by mechanical means and fractionating the envelope material in the centrifuge; cytoplasmic material is apt to be trapped inside the vesicles. In the experiments on $H$. salinarium strain I treatment with detergents gave cell-envelope vesicles appearing 'clean' inside. However, the detergents also seemed to release material from the outer layer of the cell envelope.

Brown (1963) first pointed out that lysis of the cell envelopes of halobacteria in hypotonic solutions might be due to the acidic nature of the envelope protein. At high concentrations of $\mathrm{NaCl}$ the negative charges of the protein would be neutralized by the sodium ions; upon removal of $\mathrm{NaCl}$ the negative charges would cause a dissolution of the cell envelope. The present work on Halobacterium salinarium strain I supports this general idea. Though the amino acid analysis was done on the cellenvelope vesicles and thus on a preparation contaminated with some cytoplasmic material, the bulk of the protein of the preparation stemmed from the cell envelope. The analysis shows an excess of acidic over basic amino acids of about 20 mole $\%$ (not corrected for amide) or at least 5 mole \% (corrected for amide). Cell-envelope preparations of $H$. cutirubrum (Kushner \& Onishi, 1966) and H. halobium (McClare, 1967) gave similar figures. For comparison it should be mentioned that analysis of cellenvelope preparations of non-halophilic enterobacteria (Howe, Featherston, Stadelman \& Banwart, 1965) and a marine pseudomonad (Brown, I963) gave an excess of acidic over basic amino acids of only about 9 mole $\%$ and 5 mole $\%$, respectively, uncorrected for amide.

Cell-envelope vesicles of Halobacterium salinarium strain I, dialysed against distilled water so that the structures disintegrated, yielded cell membrane flakes in the sediment after ultracentrifugation. The supernatant fluid contained the bulk of the protein, presumably acidic protein from the outer layer of the cell envelope. The sedimented fraction is probably not a 'pure' preparation of cell membrane material even after washing; it might be contaminated with, for instance, ribosomal material trapped inside the cell-envelope vesicles during their preparation. The washed sediment can, however, be considered highly enriched in the cell-membrane material. This sediment contains about $50 \%$ lipid, a considerably higher figure than those reported for purified cell membranes of Gram-positive bacteria and mycoplasmas (Salton, I967). It is difficult to imagine that the contaminating material will contribute significantly to the lipid content of the membrane fraction. On the other hand it is indeed possible that protein has been released from the cell membrane also upon removal of the salt 
by dialysis, thus leaving a simpler membrane structure with a higher lipid content than in its native state.

The carotenoids and cytochromes collect in the membrane fraction and are probably constituents of the native cell membrane, as in the case of the Gram-positive bacteria. The amino sugar-containing component can be assumed to be a part of the cell envelope rather than the cytoplasmic material contaminating the cell-envelope vesicles. The amino sugar units are probably building blocks in polysaccharide structures. Some of these structures seem to be attached to bigger structures, possibly the cell membrane, and released only when the salt concentration becomes very low.

We are greatly indebted to Mrs Asbjørg Flo for technical assistance in the preparations for electron microscopy and to siv. ing. Torunn Hauger for taking part in the late phase of the work on the amino sugar-containing component. The work was supported by a grant from The Norwegian Council for Science and the Humanities.

\section{REFERENCES}

Albertson, P.-A. (1960). Partition of Cell Particles and Macromolecules. Stockholm: Almqvist and Wiksell.

Brown, A. D. (1963). The peripheral structure of Gram-negative bacteria IV. The cation-sensitive dissolution of the cell membrane of the halophilic bacterium, Halobacterium halobium. Biochim. biophys. Acta 75, 425.

Brown, A. D. \& SHOREY, C. D. (1963). The cell envelopes of two extremely halophilic bacteria. J. cell Biol. I8, 68I.

Brown, A. D., Shorey, C. D. \& Turner, H. P. (1965). An alternative method of isolating the membrane of a halophilic bacterium. J. gen. Microbiol. 4r, 225.

CHO, K. Y., DOY, C. H., \& MERCER, E. H. (1967). Ultrastructure of the obligate halophilic bacterium Halobacterium halobium. J. Bact. 94, 196.

FolCh, J., Lees, M. \& STANLeY, G. H. S. (1957). A simple method for the isolation and purification of total lipids from animal tissues. J. biol. Chem. 226, 497.

GlauerT, A. M. \& ThORNLEY, M.J. (1966). Glutaraldehyde fixation of Gram-negative bacteria. Jl R. microsc. Soc. 85, 449.

Holmes, P. K., Dundas, I. E. D. \& Halvorson, H. O. (1965). Halophilic enzymes in cell-free extracts of Halobacterium salinarium. J. Bact. 90, 1159.

Howe, J. M., Featherston, W. R., Stadelman, W. J. \& Banwart, G. J. (1965). Amino acid composition of certain bacterial cell-wall proteins. Appl. Microbiol. 13, 650.

KellenBerger, E., RYTER, A. \& SéchAUd, J. (1958). Electron microscope study of DNA-containing plasma. J. biophys. biochem. Cytol. 4, 671.

KushNER, D. J. \& ONISH, H. (1966). Contribution of protein and lipid components to the salt response of envelopes of an extremely halophilic bacterium. J. Bact. 91, 653.

Kushner, D. J., BAYLeY, S. T., Boring, J., Kates, M. \& Gibbons, N. E. (1964). Morphological and chemical properties of cell envelopes of the extreme halophile, Halobacterium cutirubrum. Can. J. Microbiol. ro, 483.

LARSEN, H. (1962). Halophilism. In The Bacteria. Ed. by I. C. Gunsalus \& R. Y. Stanier, vol. 4, p. 297. New York: Academic Press.

LARSEN, H. (1967). Biochemical aspects of extreme halophilism. In Advances in Microbial Physiology. Ed. by A. H. Rose \& J. F. Wilkinson, vol. I, p. 97. London: Academic Press.

Larsen, H., Omang, S. \& Steensland, H. (1967). On the gas vacuoles of the halobacteria. Arch. Mikrobiol. 59, 197.

LAYNE, E. (1957). Spectrophotometric and turbidimetric methods for measuring proteins. In Meth. Enzym. 3, 447.

LIAAEN JENSEN, S. (1960). Bacterial carotenoids. VI. A note on the constitution of bacterioruberine $\alpha$. Acta chem. scand. 14, 950. 
MCClARE, C. W. F. (1967). Bonding between proteins and lipids in the envelopes of Halobacterium halobium. Nature, Lond. 216, 766.

MOHR, V. \& LARSEN, H. (1963). On the structural transformation and lysis of Halobacterium salinarium in hypotonic and isotonic solutions. J. gen. Microbiol. 31, 267.

MoORE, S. (1963). On the determination of cystine as cysteic acid. J. biol. Chem. 238, 235.

MOORE, S., SPACKMAN, D. H. \& STEIN, W. H. (1958). Chromatography of amino acids on sulphonated polystyrene resins. Analyt. Chem. 30, 1185 .

Noltmann, E. A., Mahowald, T. A. \& KuBY, S. A. (1962). Studies on adenosine triphosphate transphosphorylases. J. biol. Chem. 237, 1146.

ONISH, H. \& KUSHNER, D. J. (1966). Mechanism of dissolution of envelopes of the extreme halophile Halobacterium cutirubrum. J. Bact. 91, 646.

Penso, G. (1947). Il rosso dei bacallari-Etiologia, commestibilità, bonifica e prevenzione. Rc. Ist. sup. Sanità 10, 563.

REINER, M. (I94I). Manual of Clinical Chemistry. New York: Interscience.

Rhuland, L. E., Work, E., Denman, R. F. \& Hoare, D. S. (1955). The behaviour of the isomers of $\alpha, \epsilon$-diaminopimelic acid on paper chromatograms. J. Am. chem. Soc. 77, 4844 .

RoNDLE, C. J. M. \& MORGAN, W. T. J. (1955). The determination of glucosamine and galactosamine. Biochem. J. 6r, 586.

Salton, M. R. J. (1967). Structure and function of bacterial cell membranes. A. Rev. Microbiol. 21, 417.

STEENSLAND, H. (1967). Electron microscope studies of the surface layers of halobacteria. Abstr. 4th Meeting Federation Europ. Biochem. Soc. p. 49. Oslo: Universitetsforlaget.

StOeCKenIUs, W. \& Rowen, R. (1966). Fine structure of the cell envelope and internal membranes of Halobacterium halobium. Abstr. 6th int. Congr. Electron Microscopy, Kyoto, vol. 2, p. 273. Tokyo: Maruzen Co.

StOECKENIUS, W. \& Rowen, R. (1967). A morphological study of Halobacterium halobium and its lysis in media of low salt concentration. J. cell Biol. 34, 365.

Tristram, G. R. \& SMITH, R. H. (1962). The amino acid composition of some purified proteins. In Advances in Protein Chemistry. Ed. by C. B. Anfinsen, M. L. Anson \& J. T. Edsall, vol. I8, p. 227. New York and London: Academic Press.

YeMm, E. W. \& CockING, E. C. (1955). The determination of amino-acids with ninhydrin. Analyst, Lond. 80, 209.

\section{EXPLANATION OF PLATES}

Plate I

Fig. I. Section of Halobacterium salinarium strain I. $\times 140,000$. Organism kept at optimal $\mathrm{NaCl}$ concentration $(4 \cdot 3 \mathrm{M})$.

Fig. 2. Section of Halobacterium sp. strain 5. $\times 140,000$. Organism kept at optimal $\mathrm{NaCl}$ concentration $(4 \cdot 3 \mathrm{M})$.

Fig. 3-4. Sections of $H$. salinarium strain I. $\times 140,000$. Organism exposed to half strength $(2 \cdot 2 \mathrm{M})$ $\mathrm{NaCl}$. Fig. 3, unbroken cells. Fig. 4, broken cells.

\section{Plate 2}

Fig. 5-7. Sections of cell-envelope fragments of $H$. salinarium strain $1 . \times 50,000$. Fragments kept at optimal $\mathrm{NaCl}$ concentration ( $4 \cdot 3 \mathrm{M}$ ). Fig. 5, no detergent. Figures 6 and 7 , cells disintegrated in the presence of $2 \%$ Tween 80 and $0.005 \%$ Triton X 100, respectively.

Fig. 8-9. Sections of cell membranes of $\boldsymbol{H}$. salinarium strain I. $\times$ 100,000. Membranes obtained by dialysis against $0.025 \mathrm{M}-\mathrm{MgCl}_{\mathbf{2}}$ (Fig. 8) and by dialysis against water (Fig. 9). 

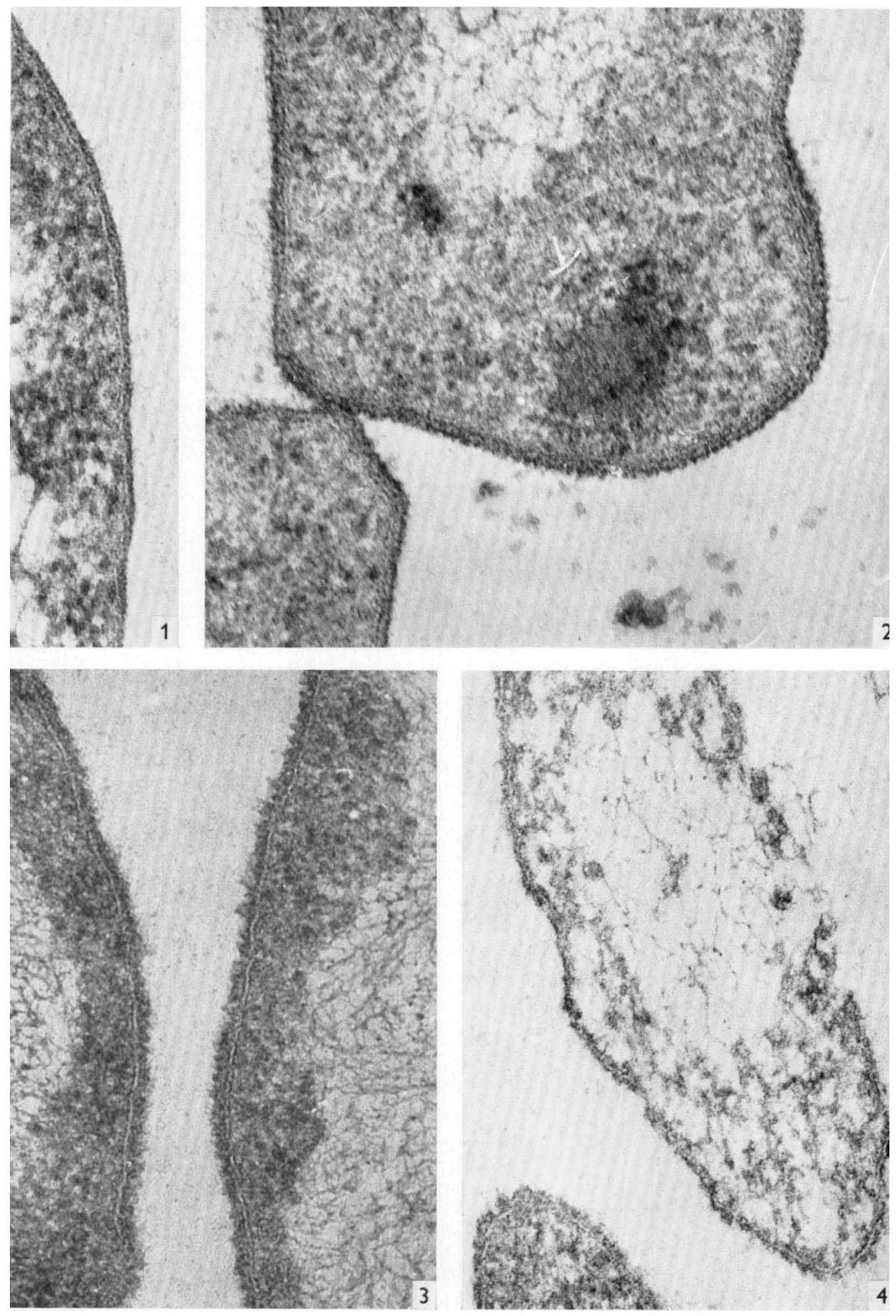

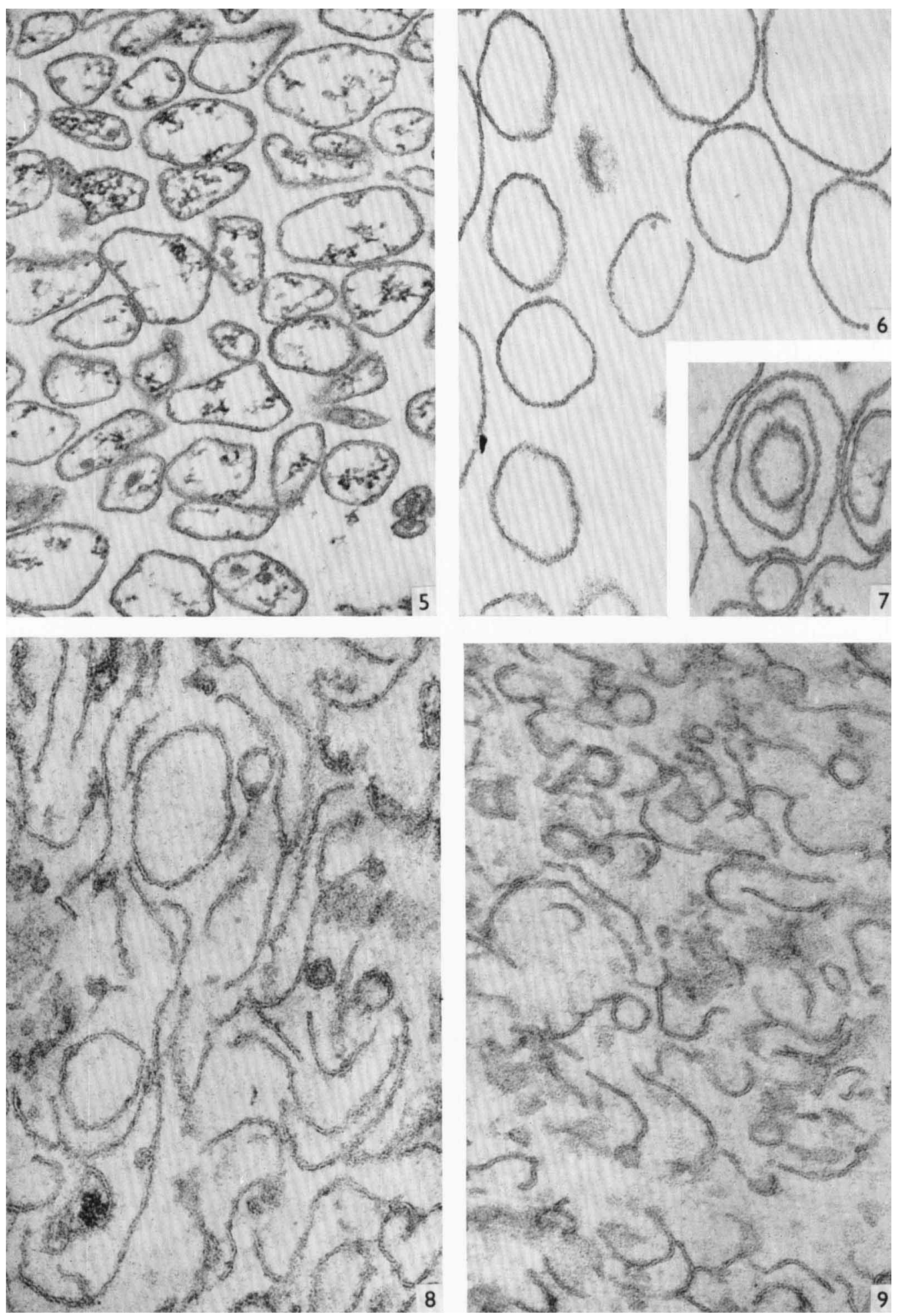